\title{
USE OF ZONING RESTRICTIONS TO RESTRAIN PROPERTY OWNERS FROM ALTERING OR DESTROYING HISTORIC LANDMARKS
}

Because of the actual or imminent destruction of many historically significant buildings, ${ }^{1}$ there has been a strong protest from those Americans who wish to preserve the remaining vestiges of our history and cultural background. In response to this protest, governmental action has been taken at the federal, ${ }^{2}$ state, ${ }^{3}$ and local ${ }^{4}$ levels. State and local governments have borne the brunt of this effort. These authorities can

1. Over half of the 12,000 bnildings listed in the Historic Building Survey undertaken by the federal government in 1933 had been razed by 1970 . Conti, Preserving the Past, Wall Street J., Aug. 10, 1970, at 1, col. 1. The threat to historical landmarks is greatest in urban areas, where the demands for additional housing and commercial space result in very high property values.

2. The federal government's interest in preserving our national heritage was evidenced by the passage of the National Historic Preservation Act of 1966. 16 U.S.C. $\S \S 470$ et seq. (1970).

The Act has a threefold purpose:

(1) to establish the National Register of districts, sites, and structures signifi-

cant in American history, architecture, archaeology, and culture;

(2) to enconrage programs at state and local levels to protect such properties; and

(3) to establish the Advisory Council on Historic Preservation which will coordinate public and private preservation efforts.

The focus of the Act is on protection of the National Register properties through matching grants-in-aid to states and to the National Trust for Historic Preservation, id. $\S 470(\mathrm{a})$, and through training and education, id. $\$ 470(\mathrm{j})(5)$. Thus, federal participation in historic preservation efforts is chiefly supplemental to state and local efforts.

3. Every state now has passed some form of historic preservation law. See J. MoRrison, Historic PReservation LAW 6-9, 12-15, 61-126 (1965).

The various preservation steps employed by states include state-wide surveys of historic landmarks, the creation of historic districts, acquisition by eminent domain of historic property or of restrictive easements over the facade of such buildings, tax concessions to owners who preserve their historic property, and limitations on competing public projects. For an evaluation of these varions techniques employed by state preservation legislation and a description of the various results achieved, see Wilson \& Winkler, The Response of State Legislation to Historic Preservation, 36 Law \& CoNTEMP. Prob. 329 (1971).

4. Local preservation efforts usually begin with lobbying and presentation of bills to the state legislature. Such bills tend to delegate to local authorities the powers necessary for historic preservation. See generally J. Morrison, supra note 3, at 9-11, 1519, 129-86. However, some local governments have instituted preservation programs without specific state authorization. The Supreme Conrt of New Mexico upheld the power of Santa Fe under a general zoning enabling act to create an historic district without express legislative authority. See City of Santa Fe v. Gamble-Skogmo, Inc., 73 N.M. 410,389 P.2d 13 (1964). For a discussion of the responses of New York City and New Orleans to historic preservation, see notes 64-66 and 95-96 infra and accompanying text. See also Tinkcom, The Philadelphia Historical Commission: Organization and Procedures, 36 LAW \& CONTEMP. ProB. 386 (1971). 
rely upon two powers to preserve historic monuments: eminent domain and the police power. ${ }^{5}$ Although historic preservation is a valid use of the power of eminent domain, ${ }^{8}$ the exercise of this power carries with it a requirement of compensating the landowner, ${ }^{7}$ and the cost of compensating owners usually will prohibit widespread application of the power of eminent domain. ${ }^{8}$ Therefore, the only generally effective mechanisms for historic preservation have been derived from the police power, and the most effective use of the police power for this purpose has been the use of zoning restrictions. ${ }^{9}$

5. Other less common methods include tax incentives and urban renewal programs. See Comment, Legal Methods of Historic Preservation, 19 Buffalo L. Rev. 611, 616 (1970).

An alternative approach, the "Chicago Plan" of development rights transfer, has been suggested by Professor Costonis. See Costonis, The Chicago Plan: Incentive Zoning and the Preservation of Urban Landmarks, 85 HARv. L. REv. 574 (1972). This proposal was inspired by New York City's plan for transfer of authorized development rights from landmark sites to adjacent lots in certain districts within New York City. New YORK, N.Y., ZONING RESOLUTION art. VII, ch. 4, §§ 74-79, -791 to -793 (1971). Under the Chicago Plan, the landmark commission would obtain an appraisal of the economic effects of landmark designation and then determine a compensation "package" for the owner, consisting of an authorization to transfer the development rights of up to one hundred per cent of the landmark's lot area and a reduction in the real estate tax on the lot. Costonis, supra at 591-93.

6. As early as $\mathbf{1 8 9 6}$ the Supreme Court held that the power of eminent domain may be exercised properly to preserve historic property. United States v. Gettysburg Elec. Ry., 160 U.S. 668 (1896); accord, Roe v. Kansas ex rel. Smith, 278 U.S. 191 (1929), dismissing appeal from State ex rel. Smith v. Kemp, 124 Kan. 716, 261 P. 556 (1927). In allowing the federal government to condemn land for the Gettysburg National Military Reservation, the Supreme Court noted that discussion of the day conflicted over two proposed definitions of "public use"; one stressing the importance of a "right to use on the part of the public" and the other emphasizing "public benefit, utility or advantage." 160 U.S. at 674. The Court concluded that state benefit from inspiration of partriotism, love of country, and appreciation for the historical significance of the Civil War justifies public use of the property. Id. at 681-82.

The Gettysburg Electric Railway case has been followed in upholding acts of eminent domain by the states for the purpose of historic preservation. See e.g., State ex rel. Smith v. Kemp, 124 Kan. 716, 261 P. 556 (1927), appeal dismissed, 278 U.S. 191 (1929). The Supreme Court of Kansas upleld a state condemnation proposal for a site of historical interest. Basing the decision on the "public use" doctrine, the court explained the benefits of historic preservation:

The end to be subserved by state promotion of intellectual and moral inprovement is better citizenship; and good citizenship is inculcated by giving attention to history as history is now conceived. History is no longer a record of past events. It is an illuminating account of the expanding life of man in all its manifestations, revealing low each stage of civilization grows out of preceding stages, revealing how the past still lives in us and still dominates us, and enabling us to profit by what has gone before. So considered, history is inspirational. Id. at $721,261 \mathrm{P}$. at 558 .

7. Williams v. Parker, 188 U.S. 491, 494 (1903).

8. See Lutheran Church in America v. City of New York, 35 N.Y.2d 121, 134, 316 N.E.2d 305, 313, 359 N.Y.S.2d 7, 18 (1974) (dissenting opinion).

9. Non-zoning uses of the pohice power to protect landmarks include anti-neglect 
A severe type of zoning restriction which is finding increasing use is simply to forbid private owners of historical structures to demolish or alter their property without approval of the local preservation coinmission. ${ }^{10}$ Because of the onerous effect of such regulations, affected property owners are beginning to challenge them, either to force abandonment of the restrictions or to force the government to coinpensate thein. ${ }^{11}$ Courts have differed in their responses to these challenges. The inain issue presented is whether the restrictions constitute a taking of property without compensation in violation of due process. If so, only the power of eminent domain, with its correlative requirement of compensation, remains. The effect of finding a "taking" will generally be to frustrate the historic preservation effort. ${ }^{12}$

This Note will examine the constitutionality of imposing such zoning restrictions without compensation. First, it will present the several current tests for "taking." Thereafter it will examine the nature of the constitutional standards for historic preservation efforts generally. Next it will present the two current, contrasting judicial attitudes toward restrictions upon owners' rights to demolish or alter their historic buildings. The Note concludes that such restrictions are generally constitutional when the proper legal standard is applied.

\section{CONSTITUTIONAL STANDARDS FOR Historic PRESERVATION ORDINANCES}

\section{The "Taking" Concept}

Although regulations upon the use of property must satisfy the general tests applicable to all uses of the police power, ${ }^{13}$ the principal question involved in governmental regulations for the preservation of private property is whether the restriction is of such inagnitude as to constitute a taking. Whenever the restrictions on the owner's free use

ordinances and anti-demolition statutes. While these regulations are based on the police power to protect the health and safety of the public in an historic site or district, they are generally more stringent than safety standards applicable to other areas. See NEw York, N.Y., CharTer \& ADMIN. CODE, ch. 8A, § 207-10.0 (1971). Such anti-neglect ordimances are vital to thwart the unsuccessful apphicant for demolition who decides to let his property totally deteriorate in order to circumvent the historic preservation laws. Id. \$ 207-11.0 (1971).

10. See e.g., id. ch. 9-A, §§ 207-1.0, et seq. (1965); New ORleANs, LA., CitY Code $\S \S 65-1$ to $-33(1940)$.

11. See e.g., Maher v. City of New Orleans, 371 F. Supp. 653 (E.D. La. 1974); Lutheran Church in America v. City of New York, 35 N.Y.2d 121, 316 N.E.2d 305, 359 N.Y.S.2d 7 (1974).

12. See note 8 supra and accolnpanying text.

13. See notes 46-53 infra and accompanying text. 
and enjoyment are sufficient to amount to a "confiscation" of his property, there is a taking. ${ }^{14}$ If a taking is involved, due process demands compensation to the owner of the historic property. ${ }^{15}$

In the absence of clear guidance from the Supreme Court, a confusing assortment of tests has arisen to describe what constitutes a takmg. ${ }^{10}$ Among the numerous standards suggested, three general tests of judicial origin enjoy the most substantial authority in determining whether a taking has occurred: the "physical invasion" test, the "noxious use" test, and the "diminution-in-value" test. Not infrequently courts will employ a combination of these tests without clearly defining the different standards being used. ${ }^{17}$

The Physical Invasion Test. The "physical invasion" test requires the government to compensate whenever it takes physical possession of the affected premises. ${ }^{18}$ In such cases the confiscation is apparent.

14. See 2 J. SACKMan, Nichols' The LAW of Eminent Domain § 6.1[1] (rev. 3d ed. 1974).

An interference with the value of private property has been held to constitute a taking. See, e.g., Eyherabide v. United States, 345 F.2d 565 (Ct. Cl. 1965); Forster v. Scott, 136 N.Y. 577, 32 N.E. 976 (1893); Penn v. Carolina Virginia Coastal Corp., 231 N.C. 481, 57 S.E.2d 817 (1950); Steinle v. City of Cincinnati, 142 Ohio 550, 53 N.E.2d 800 (1944). Contra, Ledbetter v. Beach, 220 Tenn. 623, 421 S.W.2d 814 (1967).

15. Pennsylvania Coal Co. v. Mahon, 260 U.S. 393, 415 (1922). In Pennsylvania Coal the appellant successfully argued that "[w] in any way or soine incorporeal hereditament is taken away which was appurtenant thereto, it constitutes as much a taling as if the land itself had been appropriated." Id. at 395 (citations omitted).

16. The Court has not developed a clearer definition of "taking" since the Pennsylvania Coal case. At times the Court still follows the "physical invasion" test discussed in notes 18-19 infra and accompanying text. See, e.g., Umited States v. Central Eureka Mining Co., 357 U.S. 155, 165-66 (1958).

17. See note 21 infra and text accompanying notes $25-26$ infra.

18. The physical invasion test originated in the old state cases. See e.g., Commonwealth v. Alger, 61 Mass. (7 Cush.) 53 (1851); Coates v. City of New York, 7 Cow. 585 (N.Y. Sup. Ct. 1827).

The United States Supreme Court employed this test in Transportation Co. v. Chicago, 99 U.S. 635 (1878), where a landowner complained of property damage resulting from the city's construction of a nearby tunnel. In upholding a verdict for the city, the Court emphasized the fact that there was no physical invasion of the claimant's property:

[A]cts done in the proper exercise of governmental powers, and not directly encroaching upon private property, though their consequences may impair its use, are universally held not to be a taking within the meaning of the constitutional provision. They do not entitle the owner of such property to coinpensation from the State or its agents, or give him any right of action. Id. at 642.

See also Mugler v. Kansas, 123 U.S. 623 (1887). But see Pumpelly v. Green Bay Co., 80 U.S. (13 Wall.) 166 (1872). In the latter case the Court held that permanent flooding of private property might be regarded as a "taking":

It would be a very curious and unsatisfactory result, if . . . it shall be held that if the government refrains from the absolute conversion of real prop- 
However, while it is universally agreed that the state nust provide compensation when it occupies the property, an actual physical invasion of the property is no longer an absolute requisite for the owner's right to compensation. ${ }^{19}$

The Noxious Use Test. Another judicial approach to the problem of taking has been the "noxious use" test, which defines a specific, valid exercise of the police power. Under this test, the court examines the nature of the property use which is limited by a governmental regulation. If the use so affected is determined to be prejudicial to public health, safety, or morals, then the government may validly regulate it, and any resulting decrease in the value of the property need not be compensated. ${ }^{20}$

On the other hand, as a corollary to the noxious use test, some courts have concluded that where a municipality cannot show that a nuisance or liarm is benig abated, then the property owner has suffered a taking. ${ }^{21}$ Under this corollary test, if the purpose of the regulation is to secure some benefit for the entire community at the expense of the landowners rather than to prevent a nuisance, then there is a taking. Zoning regulations prohibiting draining and filling swampland ${ }^{22}$ and

erty to the uses of the public it can destroy its value entirely, can inflict irreparable and permanent injury to any extent, can, in effect, subject it to total destruction witlout making any compensation, because in the narrowest sense of that word, it is not taken for the public use. Sucli a construction would pervert the constitutional provision into a restriction upon the rights of the citizen ... and make it an authority for invasion of private riglit under the pretext of the public good, which had no warrant in the laws or practices of our ancestors. Id. at 177-78.

However, the Court pointed out in Transportation Co. that there was a plrysical invasion of the private property and a practical ouster by the floodwaters in Pumpelly. 99 U.S. at 642 .

19. See text accounpanying note 28 infra.

20. For example, the state, without payment of compensation, may prohibit the operation of a brickyard in a residential neighborhood on the grounds that the brickyard is offensive to the public health. Hadaclieck v. Sebastian, 239 U.S. 394 (1915). See also Goldblatt v. Town of Hempstead, 369 U.S. 590 (1962) (prohibition of sand and gravel pits); L'Hote v. New Orleans, 177 U.S. 587 (1900) (forbiddance of liouses of prostitution outside of designated area); Mugler v. Kansas, 123 U.S. 623 (1887) (ban on alcoholic beverage manufacturing plants); Fertilizing Co. v. Hyde Park, 97 U.S. 659 (1878) (prohibition of fertilizer manufacturing plant).

21. See e.g., State v. Johnson, 265 A.2d 711, 716 (Me. 1970); Aronson v. Town of Sliaron, 346 Mass. 598, 602-04, 195 N.E.2d 341, 344-45 (1964); Morris County Land Improvement Co. v. Township of Parsippany-Troy Hills, 40 N.J. 539, 554-56, 193 A.2d $232,241-42$ (1963). In these three cases the courts invalidated ordinances in situations where no nuisance or harm was perceived on the basis that a public benefit, the burden of which sliould be borne by the whole community, was secured by the regulation. The courts also relied on the diminution-in-value test. See notes 25-28 infra and accompanying text.

22. See State v. Johnson, 265 A.2d 711, 716 (Me. 1970); Morris County Land Im- 
preventing development of rural property into small, economically feasible lot sizes ${ }^{23}$ in order to maintain a more pleasant community have been held to be takings under this test. The premise of this "noxious use" corollary is that the costs of such public benefits should be borne by the entire public rather than the individual landowner. ${ }^{24}$

The Diminution-in-Value Test. The standard which is probably most often used (sometimes as an alternate to the noxious use test) is the "diminution-in-value" test. ${ }^{28}$ This test dates back to Pennsylvania Codl Co. v. Mahon, ${ }^{27}$ a 1922 case, where Justice Holmes stated for the Supreme Court:

Government hardly could go on if to some extent values incident to property could not be diminished without paying for every such change in the general law. As long recognized, some values are enjoyed under an implied limitation and must yield to the police power. But obviously the inplied limitation must have its limits, or the contract and due process clauses are gone. One fact for consideration in determining such limits is the extent of the diminution. When it reaches a certain magmitude, in most if not all cases there must be an exercise of eminent domain and compensation to sustain the act. ${ }^{28}$

Thus, under this standard the value of existing interests in property may be diminished somewhat by a governmental regulation without the requirement of conipensation. However, if the regulation substantially reduces the value of the property, the government inust provide compensation.

A recent modification of the diminution-in-value test by the state courts $^{20}$ has attracted notice for its significant limitation on the original

provement Co. v. Township of Parsippany-Troy Hills, 40 N.J. 539, 554-56, 193 A.2d $232,241-42$ (1963).

23. See Aronson v. Town of Sharon, 346 Mass. 598, 602-04, 195 N.E.2d 341, 34445 (1964).

24. State v. Johnson, 265 A.2d 711, 716 (Me. 1970).

25. See note 21 supra.

26. See, e.g., Dooley v. Town Plan \& Zoning Comm'n, 151 Conn. 304, 197 A.2d 770 (1964) (invalidating regulation which prevented developinent of flood plain); La Salle Nat'l Bank v. County of Cook, 12 III. 2d 40, 145 N.E.2d 65 (1957) (invalidating regulation zoning as residential property suitable only for industrial or commercial use); State v. Johnson, 265 A.2d 711 (Me. 1970) (setting aside regulation which prevented landowner from filling in his marsh); Aronson v. Town of Sharon, 346 Mass. 598, 195 N.E.2d 341 (1964) (declaring void zoning regulation which prevented developinent of small, economically feasible lot sizes); Arverne Bay Constr. Co. v. Thatcher, 278 N.Y. 222, 15 N.E.2d 587 (1938) (setting aside zoning ordinance which restricted plaintiff's property to residential use, though it was unsuitable for residential use).

27. 260 U.S. 393 (1922).

28. Id. at 413.

29. See Candlestick Properties, Inc. v. San Francisco Bay Conservation \& Dev. 
rule. ${ }^{30}$ Under this approach, where the regulation seeks to preserve the status quo rather than to improve the public condition, the impact upon the value of the land for its potential use does not constitute a taking. Courts which have employed this test have upheld ordinances similar to those invalidated under the "noxious use" corollary. ${ }^{31}$ For example, in Just v. Marinette County, ${ }^{32}$ the Supreme Court of Wisconsin upheld a shoreland zoning ordinance forbidding landowners from placing fill inaterial on their wetland property without a conditional use permit. While noting that extremely burdensome restrictions on the property would amount to a taking under the traditional diminutionin-value test, ${ }^{33}$ the court held that no taking was involved (and thus no compensation required) because the ordinance served to prevent harm froin a change in the natural character of the property, rather than to secure any additional public benefit: ${ }^{34}$

It seems to us that filling a swamp not otherwise commercially usable is not in and of itself an existing use, which is prevented, but rather is the preparation for some future use which is not indigenous to a swamp. Too inuch stress is laid on the right of an owner to change commercially valueless land when that change does damage to the rights of the public. ${ }^{35}$

Regardless of the severity of the restrictions, the modified diminutionin-value standard does not require compensation for limitations on potential use of property whicls serve to maintain the existing condition. A regulation which would be invalidated under the "noxious use" corollary as serving the public benefit at the expense of the individual

Comm'n, 11 Cal. App. 3d 557, 89 Cal. Rptr. 897 (1970); Just v. Marinette County, 56 Wis. 2d 7, 201 N.W.2d 761 (1972).

30. See Berger, A Policy Analysis of the Taking Problem, 49 N.Y.U.L. Rev. 165, 176-77 (1974).

31. Compare Candlestick Properties, Inc. v. San Francisco Bay Conservation \& Dev. Comm'n, 11 Cal. App. 3d 557, 89 Cal. Rptr. 897 (1970) and Just v. Marinette County, 56 Wis. 2d 7, 201 N.W.2d 761 (1972) with State v. Johnson, 265 A.2d 711 (Me. 1970) and Morris County Land Improvement Co. v. Township of Parsippany-Troy Hills, 40 N.J. 539, 193 A.2d 232 (1963i).

32. 56 Wis. $2 \mathrm{~d} 7,201$ N.W.2d 761 (1972).

33. Id. at 15,201 N.W.2d at 767.

34. It should be noted that this distinction between harm and benefit is similar to the noxious use standard. See notes 20-24 supra and accompanying text.

When the court views the regulation as securing a benefit for the community, then it is more likely to require compensation to the landowner. However, when the court finds only a prevention of harm to the public, then the regulation will be upheld as a proper exercise of the police power. Given the same fact situation, courts which take the former view will probably achieve a result which will differ from that of courts which follow the latter view. See note 31 supra and accompanying text.

35. Id. at 22,201 N.W.2d at 770. 
landowner might nevertheless be upheld under the modified diminution-im-value test if the public benefit to be derived from the regulation were limited to preventing a detrimental change in the character of the property. ${ }^{30}$

This emerging test is a fair one in that it strikes a proper balance between the duty to compensate landowners for the impairment of their property values and the need for flexible use of the police power to protect the environment. Under the modified diminution-in-value standard, those restrictions which severely limit the owner's legitimate expectations of continued use would require compensation, while frustration of more speculative expectations of development potential would not. Especially simce today's historic preservation efforts are well publicized, restrictions on development of historic properties will not violate normal community expectations. ${ }^{37}$

The Arbitral-Enterprise Test. In response to the confusing array of judicial standards for takmg, commentators have suggested numerous additional tests. ${ }^{38}$ However, of these suggestions, only Professor Sax's proposed arbitral-enterprise distinction ${ }^{39}$ has received explicit judicial recognition. ${ }^{40}$ Under this standard, when the state resolves disputes between competing private parties in its arbitral capacity, any resulting decrease in value of the landowner's property requires no compensation regardless of the severity of the loss. ${ }^{41}$ On the other hand, when the government uses private resources for the public benefit, it acts in its enterprise capacity and must compensate the owner for the taking. ${ }^{42}$ For instance, in Morris County Land Improvement Co. $v$. Township of Parsippany-Troy Hills ${ }^{43}$ the township restricted the use of the plaintiff's land to public recreational, wildlife sanctuary, and sewage treatment plant uses. There was a taking because the regulated property had been added to the government's resources in several of its enterprise capacities.

36. See note 34 supra and accompanying text.

37. The sense of justice is offended when normal community expectations are frustrated by legal decisions. See E. Cahn, The Sense of InJustice 20-21 (1949).

38. See generally Berger, supra note 30 , at $170-95$.

39. For an analysis of the problem of "taking" based upon the arbitral-enterprise distinction, see Sax, Takings and the Police Power, 74 YALE L.J. 36, 61-76 (1964).

40. See Lutheran Church in America v. City of New York, 35 N.Y.2d 121, 12829,316 N.E.2d 305, 310, 359 N.Y.S.2d 7, 14 (1974).

41. Sax, supra note 39 , at $62-63$.

42. Id. at 63.

43. 40 N.J. 539, 193 A.2d 232 (1963). See also Vernon Park Realty, Inc. v. City of Mount Vernon, 307 N.Y. 493, 121 N.E.2d 517 (1954) (court declared unconstitutional zoning ordinance restricting use of plaintiff's property to parking and servicing of autoinobiles). 
Zoning, the regulation of land use under the police power, has proved the most effective means of maintaining the historic character and appearance of culturally important sites. ${ }^{44}$ However, the use of this power is subject to significant constitutional restrictions; in addition to the taking doctrine, further limitations are imposed by the due process and equal protection clauses. Although these general concepts are familiar, their application to zoning ordinances raises special problems. ${ }^{45}$

Due process requires a "public use" for exercise of the police power through zoning. ${ }^{46}$ Zoning is essentially negative in operation, placing certain restrictions on the use of property. ${ }^{47}$ The inajor aspect of the utilization of zoning laws for historic preservation has been to control the external appearance of structures within district boundaries. Such aesthetic considerations satisfy the public use requirement for exercise of the police power as promotion of the public welfare..$^{48}$

44. See text accompanying note 9 supra.

45. See Comment, Constitutional Law-Due Process-Zoning-Suburban Township Zoning Ordinance Which Does Not Provide for Apartments as Permissible Residential Use Violates Due Process, 23 ALA. L. REv. 157 (1970); Comment, Constitutional Law -Equal Protection Extended to Municipal Services-Possible Application to Exclusionary Zoning, 17 N.Y.L. Forum 599 (1971); Comment, The Constitutional Implications of a Restrictive Definition of Family in Zoning Ordinances, 17 S.D.L. REv. 203 (1972); Comment, Zoning, Communes and Equal Protection, 1973 Urban L. ANNuad 319; Note, Constitutional Law-Equal Protection-Zoning-Snob Zoning: Must a Man's Home Be a Castle?, 69 MiCH. L. REv. 339 (1970); Note, The Constitutionality of Local Zoning, 79 YALE L.J. 896 (1970); 83 HARV. L. REv. 679 (1970).

46. Village of Euclid v. Ambler Realty Co., 272 U.S. 365, 387 (1926).

47. 2A J. SACKMAN, supra note 14, \$ 7.519[1], at 7-248.

48. Many earlier cases were strongly opposed to zoning on the basis of aesthetics. People ex rel. Wineburgh Advertising Co. v. Murphy, 195 N.Y. 126, 135, 88 N.E. 17, 20 (1909); City of Youngstown v. Kahn Bros. Bldg. Co., 112 Ohio St. 654, 661, 148 N.E. 842,844 (1925). However, as early as 1911 there was some recognition of aesthetics as a valid consideration in zoning ordinances. St. Louis Gunning Advertising Co. v. City of St. Louis, 235 Mo. 99, 137 S.W. 929 (1911). The Gunning decision was based on some contrived considerations as well as aesthetics (billboards spread fire, hinder firefighters, and may blow down on pedestrians; dumping of litter and prostitution occur behind them; criminals lie in wait behind them; and they obstruct sunshine and air).

Later decisions began more openly to consider aesthetics as a valid basis for zoning. See, e.g., General Outdoor Advertising Co. v. Department of Pub. Parks, 202 Ind. 85, 95, 172 N.E. 309, 312 (1930); Ware v. City of Wichita, 113 Kan. 153, 157, 214 P. 99, 101 (1923); Dowsey v. Village of Kensington, 257 N.Y. 221, 230, 177 N.E. 427, 430 (1931); State ex rel. Saveland Park Holding Corp. v. Wieland, 269 Wis. 262, 27172, 69 N.W.2d 217, 222, cert. denied, 350 U.S. 841 (1955).

The first case where purely aesthetic reasons were used to uphold an ordinance was City of Miami Beach v. Ocean \& Inland Co., 147 Fla. 480, 3 So. 2d 364 (1941). Cf. City of New Orleans v. Levy, $223 \mathrm{La} .14,64$ So. $2 \mathrm{~d} 798$ (1953) (court recognized relation between aesthetic considerations and economic benefit to community derived from tourist industry).

Finally the United States Supreme Court declared that aesthetic values are included 
A reasonable relation to some public use will not always suffice to save a zoning ordinance from invalidation; the equal protection clause of the fourteenth amendment requires either that all citizens be treated equally under the zoning scheme, or that there be a reasonable basis for any difference in treatment. ${ }^{49}$ The zoning regulations must be comprehensive and pursuant to a general plan in order to avoid the pitfalls of arbitrariness and unreasonableness. ${ }^{50}$ Furthermore, the zoning ordinances must be applied uniformly so that the promotion of the public welfare does not affect: a small group of individuals mequitably. ${ }^{51}$ Zoning laws which do not meet these requirenients of due process and equal protection are often invalidated as spot zoning. ${ }^{52}$ This spot zoning singles out an imdividual owner to bear a burden for the public benefit; it is therefore an unconstitutional use of the police power if due conipensation is not made to the owner. ${ }^{53}$

The use of the concept of the "historical district" has been niost successful in preserving historical sites without subjecting the measure to invalidation as spot zoning. Zoning ordinances creating an historic district maintain uniformity of an area's historic character by controlling demolition of and alterations to existing structures as well as limiting

within the concept of public welfare. Berman v. Parker, 348 U.S. 26 (1954). Since this decision, several courts have found ordinances based on aesthetics to be valid. See, e.g., Cromwell v. Ferrier, 19 N.Y.2d 263, 225 N.E.2d 749, 279 N.Y.S.2d 22 (1967); People v. Stover, 12 N.Y.2d 462, 191 N.E.2d 272, 240 N.Y.S.2d 734 (1963); Oregon City v. Hartke, 240 Ore. 35, 400 P.2d 255 (1965). See generally Minano, Aesthetic Zoning: The Creation of a New Standard, 48 J. URBAN L. 740 (1971); Newsom, Zoning for Beauty, 5 New Eng. L. Rev. 1 (1969); Norton, Police Power, Planning and Aesthetics, 7 Santa Clara LaW. 171 (1967); Comment, Zoning Aesthetics and the First Amendment, 64 Colum. L. REv. 81 (1964); Comment, Aesthetic Control of Land Use: A House Built Upon the Sand?, 59 Nw. U.L. REv. 372 (1964); Comment, Architectural Control Justified on the Basis of Property Value Protection, 1971 WASH. U.L.Q. 118; Note, Beyond the Eye of the Beholder: Aesthetics and Objectivity, 71 Mrch. L. Rev. 1438 (1973). But cf. Pennsylvania v. Morton, 381 F. Supp. 293 (D.C. Cir. 1974); Cominonwealth v. National Gettysburg Battlefield Tower, Inc., 454 Pa. 193, 311 A.2d 588 (1973) (courts rebuffed efforts of commonwealth to block construction of incongruous tower overlooking Gettysburg battlefield). For an exhaustive treatment of the issue, see Comment, The Gettysburg Tower Case: Testing Pennsylvania's Environmental Rights Amendment, 48 TEMP. L.Q. 46 (1974).

49. Lindsley v. Natural Carbonic Gas Co., 220 U.S. 61, 78 (1911).

50. Rodgers v. Village of Tarrytown, 302 N.Y. 115, 124, 96 N.E.2d 731, 735 (1951).

51. See Vernon Park Realty, Inc. v. City of Mount Vernon, 307 N.Y. 493, 121 N.E.2d 517 (1954).

52. See, e.g., Cassel v. Mayor \& City Council, 195 Md. 348, 73 A.2d 486 (1950); Page v. City of Portland, 178 Ore. 632, 641, 165 P.2d 280, 284 (1946); Weaver v. Ham, 149 Tex. 309, 232 S.W.2d 704, 709 (1950).

53. Vernon Park Realty, Inc. v. City of Mount Vernon, 307 N.Y. 493, 498-99, 121 N.E.2d 517, 519 (1954). See note 43 supra. 
construction of buildings to those which conform to the present character of the district. ${ }^{54}$

The courts have repeatedly sustained architectural control ordinances creating historic districts as valid exercises of the police power. ${ }^{55}$ For instance, the Louisiana Supreme Court in City of New Orleans $v$. Pergament $^{56}$ upheld an ordinance which required approval by the Vieux Carré Commission for any change in appearance, color, material, or architectural design or any new construction, demolition, or repair to any building in the historic district. ${ }^{57}$ The defendant was prosecuted for displaying on his building, which was without historic value, a large sign violative of the ordinance. He claimed that application of the ordinance to his building would deprive him of his property without due process of law and deny him equal protection of the laws. ${ }^{58}$

In sustaining the power of the Commission under the fourteenth amendment, the court stressed that the prescribed standards and requirements were uniform and bimding on all persons similarly situated. ${ }^{59}$ Thus, application of the prohibition (against the display of large signs in the French Quarter) to proprietors of modern buildings as well as to the owners of the ancient buildings in the district was not a discriminatory spot zoning scheme. ${ }^{60}$ The purpose of the ordinance was not only to preserve the antiquity of the old quarter, but also to maintain the "tout ensemble" of the area's unique character. ${ }^{61}$ Prohibiting eyesores is certainly essential to such preservation efforts.

Although zoning plans involving historio districts pass judicial scrutiny under the standards of due process and equal protection, dif-

54. For digests of the zoning ordinances creating various historic districts in the United States, see J. MoRRISON, supra note 3, at 129-86.

55. See, e.g., M \& N Enterprises, Inc. v. City of Springfield, 111 Ill. App. 2d 444, 250 N.E.2d 289 (1969); Rebman v. City of Springfield, 111 Ill. App. 2d 430, 250 N.E.2d 282 (1969); City of New Orleans v. Levy, 233 La. 14, 64 So. 2d 798 (1953); City of New Orleans v. Pergament, 198 La. 852, 5 So. 2d 129 (1941); City of New Orleans v. Innastato, $198 \mathrm{La}$. 206, 3 So. 2 d 559 (1941); Opinion of the Justices to the Senate (Beacon Hill), 333 Mass. 783, 128 N.E.2d 563 (1955); Opinion of the Justices to the Senate (Nantucket), 333 Mass. 773, 128 N.E.2d 557 (1955); City of Santa Fe v. Gamble-Skogno, Inc., 73 N.M. 410, 389 P.2d 13 (1964).

56. 198 La. 852 , 5 So. 2 d 129 (1941).

57. New OrLeans, La., City Code $\S \S 65-1$ to -33 (1940).

58. $198 \mathrm{La}$ at $854-55,5$ So. $2 \mathrm{~d}$ at 130.

59. Id. at 858,5 So. $2 \mathrm{~d}$ at 131 .

60. Id.

61. The court emphasized that more than the preservation of ancient buildings was necessary to the nuaintenance of the unique flavor of the Vieux Carré:

The purpose of the ordinance is not only to preserve the old buildings theinselves, but to preserve the antiquity of the whole French and Spanish quarter, the tout ensemble, so to speak, by defending this relic against iconoclasm or vandalism. Id. at 858,5 So. $2 \mathrm{~d}$ at 131 , quoted in Maher v. City of New Orleans, 371 F. Supp. 653, 663 (E.D. La. 1974). 
ferent problems arise when individual landmarks are designated for preservation. In urban areas there are often isolated historic monuments for which the creation of an historic district is not feasible. When individual structures are singled out for special restrictions, the question again arises whether there is compensable spot zoning.

\section{Judicial SCRUtiny of Zoning Regulations Limiting OWNERs' RIGHTS TO A.LTER. HISTORIC LANDMARKS}

As zoning regulations have been implemented to preserve urban landmarks, the owners of these inonuments are frequently faced with loss of potential income from development of the property. Recently owners have begun to challenge such restrictions as amounting to a taking of their property for which they are entitled to compensation. Courts have approached the issue in two ways. One view is that there is a taking whenever the owner's right to develop his property in a chosen manner is severely impaired. The other approach is that, when the preservation ordinance allows the owner a reasonable use of his property, there is no taking and therefore no requirement of compensation.

\section{Protecting Development Rights: The Expansive Approach to "Taking"}

The recent case of Luiheran Church in America v. City of New York ${ }^{02}$ introduced a broad concept of taking whereby restrictions on the owner's plans for development of his property were deemed confiscatory. In that decision, the Court of Appeals of New York held the designation of the plaintiff's Brownstone building ${ }^{03}$ as an historic landmark a violation of due process. The New York City Landmarks Preservation Law ${ }^{64}$ created the Landmarks Preservation Commission and

62. 35 N.Y.2d 121, 316 N.E.2d 305, 359 N.Y.S.2d 7 (1974), noted in 3 ForDHAM L.J. 123 (1974).

The Lutheran Church case has been followed in Penn Central Transp. Co. v. City of New York, (Sup. Ct. N.Y.), reported in 173 N.Y.L.J., Jan. 23, 1975, at 16, col. 3 (court held that Landmarks Preservation Commission could not require Penn Central to maintain Grand Central Station as landinark without compensation).

63. The building in question dated from the mid-nineteenth century. It was a significant early example of Anglo-Italiante architecture and one of the few free standing Brownstone buildings remaining in New York City. J.P. Morgan, Jr., had lived in the house for a number of years. 35 N.Y.2d at 125,316 N.E.2d at 308,359 N.Y.S.2d at 11.

64. New York, N.Y., Charter \& Admin. Code ch. 8-A, $\$ \S 207-1.0$ et seq. (1965). For a discussion of constitutional problems involved in application of the Landmarks Preservation Law, see Wolf, The Landmark Problem in New York, 22 N.Y.U. INTRA. L. REv. 99 (1967).

In Manhattan Club v. Landraarks Preservation Coinun'n, 51 Misc. 2d 556, 273 N.Y.S.2d 848 (Sup. Ct. 1966), the New York Supreme Court upheld the general ap- 
gave it power to designate individual properties as historic landmarks. Such designations are to be made after notice and a public learing. ${ }^{65}$ Subsequent to the designation the owner of the building must apply to the Landmarks Preservation Commission for permission to alter or demolish his buildimg. ${ }^{66}$

From its purchase by the Lutheran Church in $1942^{67}$ to the time of the action, the buildimg had provided offices for rehigious-corporate purposes. As the Church's office space requirements expanded, plans were made to demolish the old building and construct a new one. ${ }^{68}$ Soon thereafter, the Landmarks Preservation Commission designated the buildimg a landmark. As a result of the restrictions on alterations or demolition, the building became inadequate for the Churcli's contemplated uses. ${ }^{69}$ Because the Commission was prohibiting the owner from adapting its property to its expanded needs without providimg full compensation, ${ }^{70}$ the court of appeals held that the landmark designation amounted to a "naked taking."71

proach of the Landmarks Preservation Law. In holding that the statute was not confiscatory, the court remarked:

Petitioner is free to do as it pleases with the interior of the building. It is guaranteed a reasonable return on its investment. And if no plan can be devised to materialize this guarantee, it may make such changes as it wishes. Id. at 560,273 N.Y.S.2d at 852 .

65. New York, N.Y., Charter \& ADMin. Code ch. 8-A, \$\$ 207-2.0(a), (c), -12.0 (1965).

66. Id., $\S 207-5.0$ (a). In cases where deinolition or radical alteration is sought by the owner, the cominission probably would not grant permission.

The law contains provisions for the compensation of owners unduly burdened by the restrictions. Upon a showing by the owner seeking alteration that he is failing to realize at least a six per cent return on his property (id. $\$ 207-1.0(9)$ ), the coinunission is given discretion to ease the hardship by either effectuating a real estate tax rebate (id. $207-8.0(\mathrm{c})$ ), producing a buyer or lessee who could profitably utilize the premises without the desired alteration or demolition (id. $\$ 207-8.0$ (a)(2)(i)), or exercising the power of condemnation (id. $\S 207-8.0(\mathrm{~g})(2)$ ). However, religious corporations, such as the plaintiff in the Lutheran Church case, are not subject to the ameliorative provision allowing condemnation. Id. $\S 207-8.0(\mathrm{i})(1)$. The provisions for providing relief in cases of property devoted to charitable uses are limited to instances where the institution desires to alienate the property by sale or lease. Id. $\$ \S 207-8.0$ (a)(1), (6).

67. The building was constructed in 1853 and was used as a residence until 1942, when it was purchased by the plaintiff's predecessor, The United Lutheran Church in America. It then was converted to office use. In November, 1965, the Landinarks Preservation Commission designated the building a "landınark." 35 N.Y.2d at 124, 316 N.E.2d at 307,359 N.Y.S.2d at 10.

68. Id.

69. Id.

70. The anneliorative provision of the Landmarks Preservation Law allowing for condemnation and full compensation was not apphicable to this owner. See note $66 \mathrm{su-}$ pra.

71. Id. at 132,316 N.E.2d at 312,359 N.Y.S.2d at 16. 
The court began its scrutiny of this governmental interference with the owner's use of private property in terms of Professor Sax's arbitral-enterprise distinction. ${ }^{72}$ Noting that severe limitations on the free use of property may amount to a taking by the government in its enterprise capacity, the court found here a taking for public use:

In the instant case it could likewise be well argued that the commission has added the Morgan louse to the resources of the city by the designation (it being argued, inter alia, that the louse, as a tourist attraction because of its designation, aids the city generally), and that while sucl designations might not wreak confiscatory results in all situations (as where business might well be promoted by the desiguation) it does have that effect liere where plaintiff is deprived of the reasonable use of its land. ${ }^{73}$

After observing that the designation was neither part of a districting plan (i.e., an historic district) nor a prohibition of noxious use, ${ }^{74}$ the court concluded that the designation was confiscatory because it prohibited a use to which the property was devoted at the time the designation was made. ${ }^{75}$

The court also held that the restrictions failed to meet the traditional diminution-in-value test. ${ }^{76}$ Because the building was no longer adequate for the plaintiff's office needs, the court found that its charitable purpose would be impeded significantly by the restrictions associated with the landinark designation. ${ }^{77}$ Termination of sucll "free use" of the premises was held to be properly exercisable only under

72. Id. at $128-29,316$ N.E.2d at 310,359 N.Y.S.2d at 14 . See notes $39-42$ supra and accompanying text.

73. Id. at 130,316 N.E.2d at 311,359 N.Y.S.2d at 15.

74. Id. at 129,316 N.E.2d at 310,359 N.Y.S.2d at 14 .

75. The court of appeals indicated its finding that the designation did prohibit a use to which the property was devoted at the time of the enactment of the ordinance:

Here, plaintiff has submitted ample proof not seriously contested, that the use

to which the property has been put for over 20 years would have to cease

because of the inability under the designation to replace the building. Id.

The court found that there was a confiscation because the commission invaded the owner's right to own and manage its property:

Legitimate zoning . . . does not appropriate to public use. Where the owner can make a case for alteration or demolition the municipality would have to relinquish the designation, provide agreeable alternatives or condemn the premises. Id. at 132,316 N.E.2d at 312,359 N.Y.S.2d at 17 .

76. See notes 25-28 supra and accompanying text.

77. Id.; cf. Trustees of Sailors' Snug Harbor v. Platt, 29 App. Div. 2d 376, 288 N.Y.2d 314 (App. Div. 1968). Here the court ruled that relief must be forthcoming whenever the landmarks designation would pbysically or financially prevent or seriously interfere with carrying out the owner's charitable purpose. The court declined to declare the Landmarks Preservation Law unconstitutional, and remarked that the fact that the statute gave the commission power to provide rehef in certain situations did not restrict the court from doing so in other situations. Id. 
the power of eminent domain ${ }^{78}$ not under the police power. Thus, the court adhered to the older diminution-in-value test, with its broader protection for landowners, rather than the modified diminution-in-value rule. ${ }^{79}$

In Lutheran Church the Landmarks Preservation Law provided for the designation of single buildings throughout the city instead of the creation of historic districts. It is true that legitimate zoning must be pursuant to a comprehensive plan or policy; ${ }^{80}$ however, this requirement will not invalidate restrictions on the use of particular lots within a district, so long as the restrictions are not arbitrary and are based upon reasonable distinctions. ${ }^{81}$ The presence of a building of unusual historical or architectural significance would seem to be a reasonable basis for distinguishing one lot in midtown Manhattan from surrounding lots. ${ }^{82}$ Indeed, the coinprehensive policy promoted by sucl legislation would be to identify structures with such a distinction and ensure that the unique features are preserved. The fact that the owner of an historic building is treated differently from his neighbor, whose building is of no historic importance, does not amount to spot zoning. ${ }^{83}$ It would seein, then, that the absence of an historic district, a fact relied upon by the court, ${ }^{84}$ is without legal significance.

The court's specific analysis of the taking question also must be rejected, even if one accepts the arbitral-enterprise analysis adopted by the court. Although the court viewed the landinark designation as an enterprise function (hence, a taking), ${ }^{85}$ there was actually no use of the structure by the city to justify such a characterization. While confiscation of land for the operation of a sewage treatment plant or public park is an enterprise function, ${ }^{86}$ the landınark designation did not seek to create an easement or public right of entry, as in the case of a park. Because the preservation of the building was not in the best economic interest of the owner, but was of benefit to the whole community, the court found that there was a confiscation by government in its enter-

78. 35 N.Y.2d at 132,316 N.E.2d at 312,359 N.Y.S.2d at 15 .

79. See notes 29-37 supra and accompanying text.

80. See notes 49-53 supra and accompanying text.

81. See, e.g., Bartram v. Zoning Comm'n, 136 Conn. 89, 68 A.2d 308 (1949) (court held zoning of small business districts in otherwise exclusively residential areas was permissible as part of comprehensive municipal policy of encouraging decentralization of business in order to relieve traffic cougestion).

82. See Comment, note 5 supra, at 620.

83. See notes 52-53 supra and accompanying text.

84. 35 N.Y.2d at $124,129,316$ N.E.2d at $307,310,359$ N.Y.S.2d at 10,14 .

85. See notes 38-43 supra and accompanying text.

86. See text following note 43 supra. 
prise capacity. ${ }^{87}$ Yet, if these criteria alone were sufficient to constitute an enterprise function, many residential zoning restrictions would be prohibited under that test, since restriction of a lot to residential use would be of economic benefit to the neighborhood but not the owner. ${ }^{88}$

A more basic error is the court's expansion beyond all recognition of the "prior use" concept. Although the court held that the limitation upon the Church's use of the building for offices was confiscatory, ${ }^{89}$ the landmark designation did not in fact restrict the prior use of the building. Actually, under the Landinarks Preservation Law the plaintiff would be allowed to continue the same office use which had been conducted in the building before the designation, but would not be allowed to expand that use as its needs for further office space grew. If the court's view were adopted, many heretofore valid zoning regulations would be held to curtail the owner's prior use. For instance, a corporation would be free to violate a height restriction on its building (i.e., the inaximum height allowed for any structure on the lot) once the business expanded so as to require more office space. In contrast, under existing law the corporation would have to purchase another lot for the new construction without any coinpensation from the zoning authority. ${ }^{99}$ The facts of Lutheran Church presented a peculiarly inappropriate situation for such a departure from prior authority, since the developinent sought by the owner would have required a change in zoning. ${ }^{01}$ It is remarkable that the court upheld the plaintiff's right to demohish a building on the ground that a new building was needed for the plaintiff's corporate operations, when the proposed replacennent was prevented by unchallenged zoning restrictions.

It is evident that the court's finding of a taking arose from the fact that the owner's developinent rights were curtailed. ${ }^{02}$ The court did hint that the city might avoid the choice between condemnation and relinquishment of the designation by "agreeable alternatives."

87. Id. at 130,316 N.E.2d at 311,359 N.Y.S.2d at 15 .

88. Although the valuable increase in the area's tourism resulting from historic preservation legislation may be distinguishable from the increased value to homeowners in a residential zone, in both instances the zoning restrictions boost the marketable value of the surronnding property while limiting the commercial value of the individual lot.

89. See note 75 supra and acconpanying text.

90. See generally. Welch v. Swasey, 214 U.S. 91 (1909).

91. 35 N.Y.2d at 133 n.2, 316 N.E.2d at 313 n.2, 359 N.Y.S.2d at 18 n.2 (dissenting opinion).

92. Id. at 129, 316 N.E.2d at 310,359 N.Y.S.2d at 14, citing Vernon Park Realty, Inc. v. City of Mount Vernon, 307 N.Y. 493, 121 N.E.2d 517 (1954) (zoning ordinance limiting business use of plaintiff's property to parking antomobiles and incidental services declared to be unconstitutional confiscation).

93. 35 N.Y.2d at 132,316 N.E.2d at 312,359 N.Y.S.2d at 17 . 
ever, the court seemed to proceed on the assumption that nothing less than maximum utilization of the property for the owner's chosen purposes would be agreeable This all embracing definition of a taking would seem to preclude any historic preservation efforts without condemnation, except in the rare instance where the owner's use happens to coincide with the preservationists' goals.

\section{Protection of Historic Landmarks: The Balanced Approach to "Taking"}

Another recent case, Maher v. City of New Orleans, ${ }^{94}$ represents a more limited view of the taking concept under which historic designations that impede an owner's development plans will often be sustained. In the Maher case a federal district court upheld the constitutionality of the Vieux Carré Ordinance ${ }^{95}$ even though it was applied to prevent development of propenty. Under the ordinance any construction, demolition, or alteration to any building on any street or alley in the French Quarter must be approved by the Vieux Carré Commission. ${ }^{96}$ As in Lutheran Church, the landowner was attempting to develop his property to enhance its usefulness but was prevented froin doing so by the preservation ordinance. The plaintiff in Maher was the owner of a Victorian cottage in the Vieux Carré, which he wished to demolish and replace with an addition to his home. ${ }^{97}$ After Maher's application to deinolish the cottage was denied by the City Council ${ }^{98}$ and the state courts upheld denial of the demolition permit, ${ }^{99}$ he filed suit in federal district court seeking a declaration of the unconstitutionahty of the ordinance and an imjunction against its enforcement. ${ }^{100}$

94. 371 F. Supp. 653 (E.D. La. 1974).

95. New ORLEans, LA., CTrY CoDe $\$ \$ 65-1$ to -33 (1940). See text accompanying note 57 supra for a summary of the statute.

96. Id. $\S 65-8$.

97. Maher wished to include seven apartments in the addition for rental purposes. 371 F. Supp. at 655.

98. In March, 1963, Maher applied to the Vieux Carre Commission for a demolition permit. The commission denied the application in April, 1963, and again in September, 1963. In October, 1973, Maher applied once more to the commission, and the application was approved in December, 1963. In February, 1964, a group of property owners (Vieux Carré Property Owners and Associates, Inc.) appealed the decision to the City Council, which after a hearing overruled the commission's decision and ordered that the permit not be issued. In July, 1964, it was determined in Civil District Court for Orleans Parish that the council's decision was void since the council had considered the matter before Maher had requested a permit from the City Department of Safety and Permits. After a second hearing, in August, 1966, the City Council reaffirmed its prior decision in overruling the Vieux Carré Commission and denying the application for a demolition permit. $371 \mathrm{~F}$. Supp. at 656.

99. For reports of the case in the state courts, see Maher v. City of New Orleans, 256 La. 131, 235 So. 2d 402 (1970), aff'g 222 So. 2d 608 (La. App. 1969).

100. Jurisdiction was based upon the Declaratory Judgment Act, 28 U.S.C. $\S 2201$, 
In deciding for the City, the court held that the zoning ordinance was a valid exercise of the police power and was not confiscatory as applied to the plaintiff's cottage. Maher's contention that the general regulatory scheme of the Vieux Carré Ordinance could be accomplished only through the exercise of eminent domain was summarily dismissed. ${ }^{101}$ The validity of such architectural control ordinances which establish historic districts is well-settled. ${ }^{102}$ To the plaintiff's cliarge that the zoning classification was arbitrary as apphed to the Victorian cottage of "no historical or architectural value,"103 the court recalled the tout ensemble doctrine enunciated in City of New Orleans v. Perga$m e n t^{104}$ and deferred to the zoning authority's judgment as to the value of the cottage to the area's overall atmosphere. ${ }^{105}$

It is in this narrow conception of what constitutes a taking that the court's rationale diverges from that of Lutheran Church. The test

2281 (1970), which authorizes a three-judge court to issue an injunction restraining the enforcement, operation, or execution of any state statute upon the ground of its unconstitutionality.

101. 371 F. Supp. at 661.

102. See note 55 supra and accompanying text. If the zoning authority were required to condemn all property in such historic districts, then obviously the districts would be very small if they existed at all.

103. Pre-trial Brief for Plaintiff at 25, Maher v. City of New Orleans, 371 F. Supp. 653 (E.D. La. 1974).

104. 198 La. 852, 5 So. 2d 129 (1941). See note 61 supra and accompanying text.

105. While Maher proposed to replace the Victorian cottage with a Spanish-style building, the court deferred to the judgment of the City Council and the Vieux Carre Commission as to the preferability of preserving the cottage to the construction of a modified replica of an earlier style:

[T] he Vieux . Carré is more than a museum of French and Spanish architectural styles but is a mixture of construction unique to New Orleans, as well as a living residential and commercial neighborhood containing a lively potpourri of socio-economic and personal lifestyles. In many cases, it could well be a disservice to the "charm and distinctive character" of the Vieux Carré to permit the demolition of existing buildings in order to create new replicas of the past. 371 F. Supp. at 664.

Further, the court held that the Vieux Carré Ordinance was not an unconstitutional delegation of legislative authority because of a lack of adequate standards. Id. The fierce disagreement of the experts in this case might have suggested that the standards were too vague to be followed evenly by the Vieux Carre Commission and the City Council. However, the court noted that zoning standards need not be specific, but may be broad, general standards "so long as they are capable of a reasonable application and are sufficient to limit and define the Board's discretionary powers." Id., quoting City of Santa Fe v. Ganble-Skogmo, Inc., 73 N.M. 410, 417, 389 P.2d 13, 18 (1964). See also Gilman v. City of Newark, 73 N.J. Super. 562, 180 A.2d 365, 384 (1962); Hiscox v. Levine, 31 Misc. 2d 151, 153, 216 N.Y.S.2d 801, 804-05 (Sup. Ct. 1961); Miller v. City of Tacoma, 61 Wash. 2d 374, 388-89, 378 P.2d 464, 473 (1963).

The mandate to preserve the character of the Vieux Carré supplied a general guideline for the council and commission, and the Maher court would allow these representative bodies to make the decisions as to which buildings in the district are worthy of preservation. 371 F. Supp. at 664. 
for confiscation was whether the ordinance "goes so far as to preclude the use of the property for any purpose for which it is reasonably adapted."108 Since the cottage could be repaired and rented, the court found that the restrictions did not inake the property unusable for the purpose of rental. ${ }^{107}$ Further, it was noted that Maher presuinably could sell his property for a fair price. ${ }^{108}$ Thus, to show confiscation under this standard, the owner would have to prove that he has been deprived of a reasonable use or return from his property. A mere showing that the owner could make inuch better use of the property without the restrictions would not suffice. ${ }^{109}$

Accordingly, the Maher court did not view the denial of a demolition permit to the owner as confiscatory-since Maher could rent or sell the cottage, ${ }^{110}$ he had not been deprived of his property. It is clear that such reasoning might have led to a different result in Lutheran Church, where there was no showing that the Church could not reasonably rent or sell the existing offices in the Brownstone building. Although the rehigious corporation would be forced to seek additional office space elsewhere for its expanded needs, the Maher court would view this inconvenience as insufficient to constitute a taking so long as the prior reasonable use was unobstructed and the alternative of leasing or selling the property for a good price was available. The Maher court thus differs froin the Lutheran Church court in not viewing the serious impairment of developinent rights as a taking.

In addition to recognizing the well-established principle that valid

106. Id., quoting Summers v. City of Glen Cove, 17 N.Y.2d 307, 309, 217 N.E.2d $663,664,270$ N.Y.S.2d 611, 612 (1966).

A zoning ordinance ordinarily reduces the value of the rights of some individuals; that fact alone does not give rise to unconstitutionality. Neef v. City of Springfield, 380 Ill. 275, 282, 43 N.E.2d 947, 951 (1942). See also Michigan-Lake Bldg. Corp. v. Hamilton, 340 III. 284, 172 N.E. 710 (1930); Minkus v. Pond, 326 Ill. 467, 158 N.E. 121 (1927); City of Aurora v. Burns, 319 III. 84, 149 N.E. 784 (1925). See note 90 supra and accomanying text.

107. $371 \mathrm{~F}$. Supp. at 662 .

108. Id. It should be noted that the court assumed the property to be marketable with the restrictions, in the absence of a contrary showing by the owner, rather than requiring the city to prove this fact.

109. In Lutheran Church the right of the owner to construct another building with additional office space was upheld over the provisions of the Landmarks Preservation Law. By contrast, Maher was not allowed to construct a new apartment building on his lot: he was relegated to renting the cottage as a single family residence or performing permissible remodeling in order to rent to inore than one family. Id. No doubt, the incoine from the rental permitted under the ordinance falls short of that available from a seven-apartınent structure in the same location.

110. See notes 107-108 supra and accompanying text. 
zoning can curtail development rights, ${ }^{111}$ the Maher decision also adheres more closely to the modified diminution-in-value rule. ${ }^{112}$ The court focused on the harm to the public which would result from violations of the Vieux Carre Ordinance, as well as the benefit accruing to the public froin its enforcement. ${ }^{113}$ The New York Court of Appeals took a contrary approacl. Holding that preservation of the landmark was a benefit shared by the community, the court decided that the burden on the plaintiff for the public benefit was sufficient to constitute a taking. However, as in the case of restrictions designed to prevent harm from a cliange in the natural cliaracter of property, ${ }^{114}$ a landmark designation to preserve a building's existing condition would not be considered a taking under the modified test for diminished value.

\section{CONCLUSION}

Although the increasing concern for the preservation of historic structures has been reflected in many decisions, the Lutheran Church opinion represents serious judicial doubts about burdening a landowner with development restrictions without full compensation. Under the expansive definition of a taking, whenever the historic preservation ordinance seriously impairs the owner's development rights, a failure to compensate will result in an impermissible confiscation. In the case of urban landmarks, such ordinances will almost always significantly curtail development potential. However, budgetary restraints on preservation commissions will prohibit condenınation of inany landmarks worth saving. Thus, under the approach of the New York Court of Appeals, the fate of many historic buildings will depend on the personal inclinations and financial desires of their owners. Given the high market value of urban property, the prospects for condenination or voluntary preservation of most landmarks are bleak.

In contrast, where courts follow the balanced approach of the Maher decision, destruction of historic structures may be curbed by zoning regulations on the ground that destruction of landmarks is a liarm to the public whicl may be checked by exercise of the police power. While New York's expansive approaeh insulates the owner's

111. See note 90 supra and accompanying text.

112. See notes 29-37 supra and accompanying text.

113. For instance, the court refers to the demolition of existing buildings in the French Quarter as a "disservice to the 'charm and distinctive character' of the Vieux Carré". Id. at 664.

114. See Candlestick Properties, Inc. v. San Francisco Bay Conservation Dev. Comm'n, 11 Cal. App. 3d 557, 89 Cal. Rptr. 897 (1970); Just v. Marinette County, 56 Wis, 7, 201 N.W.2d 761 (1972). 
expanding use of his property from the restrictions of historic zoning regulations, the Maher view of taking adheres to the modified diminution-in-value test, thus protecting the owner's actual prior use of the property, while still allowing the state to limit the property's development potential insofar as necessary for preservation of its historic character. Furthermore, the test proposed in Maher would guarantee the availability of reasonable alternatives to the owner's present use of his property. Thus, meager condenination funds can be saved for those instances where preservation of our heritage would require limitation of the owner's present use. For each decision like Lutheran Church there is an irretrievable loss to this heritage. ${ }^{115}$

115. The British recently have become very aware of the need to protect their historic buildings. For a survey of the successful means employed for landmark preservation in the Umited Kingdom, see Ashworth, Contemporary Developments in British Preservation Law and Practice, 36 LAW \& CONTEMP. Prob. 348 (1971). 
